\title{
A települési hulladékkezelés és a „magyar modell”
}

\author{
Hulladékgazdálkodás - települési önkormányzat - közhatalmi jogositványok - \\ közszolgáltatási szerződés - finanszírozás
}

Napjaink egyik fontos kérdése az önkormányzatiság és az önkormányzati feladatok és hatáskörök újragondolása, annak meghatározása, hogy milyen feladatokat, közszolgáltatásokat is kell az önkormányzatoknak kötelezően ellátniuk. A kérdés megválaszolása látszólag egyszerủ; azt kell megállapítani, hogy melyek azok a közszolgáltatások, amelyek megszervezésére és finanszírozására az önkormányzatok alkalmasak. Az alkalmasságot méretgazdaságossági és hatékonysági szempontok alapján viszonylag könnyünek tünhet megállapítani különösen azoknál a közszolgáltatásoknál, melyek a közérdekủ gazdasági szolgáltatások közé tartoznak1.

Az önkormányzatok alkalmasságának megítéléséhez azonban a fenti kérdések megválaszolása nem elegendő, mert alkalmasságukat az határozza meg, hogy adott közszolgáltatási modellben milyen szerepet kapnak, s szerepüket milyen jogi feltételek között játszhatják. A jogi szabályozás egyfajta modellt hoz létre. Az önkormányzatnak e modellben kell megtalálnia helyét, eldöntenie, hogy szerepéhez milyen személyekre, eszközökre van szüksége, hogyan tudja biztosítani a közszolgáltatás ellátásához szükséges pénzügyi feltételeket. A döntések jogi formája és tartalma változatos, igazodik a helyi igényekhez, a helyi társadalom teherbíró képességéhez, a gazdasági, múszaki viszonyokhoz. Az alkalmasságot tehát két szinten is vizsgálni kell, egyrészt a jogi keretek által meghatározott modell szintjén, azaz az elmélet szintjén, másrészt a modell megvalósulása szintjén, azaz a gyakorlat szintjén. Nem állhatunk meg azonban e kétszintű vizsgálatnál, ha a modell szabályozása nem állandó, és a modell lényeges elemeit érintő jogszabályokat az állam módosítja. Ebben az esetben az alkalmasság megítéléséhez szükségessé válik a változás hatásainak vizsgálata is.

Jelen tanulmány a modellt helyezte a vizsgálat központjába. Ezért elöször röviden ismertetjük az általunk használt közszolgáltatási modell alapjait, annak alapján bemutatjuk a hulladékgazdálkodási törvény által kialakított települési hulladékkezelési

* Dr. Pump Judit környezetvédelmi szakjogász, Baja, pumppj@t-online.hu.

1 A közszolgáltatások gazdasági érdekeltség szerinti megkülönböztetésére többek között a közösségi jogalkotás miatt volt szükség. Erre vonatkozó részleteket lásd: Green Paper on Services of General Interest, Commission of the European Communities, COM(2003) 270 final (Brussels, 21. 5. 2003); Bizottsági közlemény az Európai Parlamentnek, a Tanácsnak, az Európai Gazdasági és Szociális Bizottságnak és a Régiók Bizottságának: Fehér Könyv az általános érdekű szolgáltatásokról COM(2004) 374 végleges (Brüsszel, 12. 5. 2004). 
modelleket, értékeljük az őket 2004-ben és 2005-ben ért jogszabályi módosításokat és hatásaikat, valamint véleményt formálunk az önkormányzatok alkalmasságáról.

A tanulmány egy olyan közszolgáltatás modelljét és változásait mutatja be, melynek újraszabályozása zajlik. A közszolgáltatási terület modelljeit és gyakorlatát elemző kutatóként fontosnak tartjuk megjegyezni, hogy e tanulmányban leírt modellek ismerete szükséges, de nem elégséges feltétele a jogalkotásnak. A jogszabályok elméleti elemzése önmagában ugyanis nem alkalmas arra, hogy feltárja a modell müködési rendellenességét kiváltó okokat, ehhez a gyakorlat elemzésére is szükség van, hiszen az alapján állapítható meg csak az, hogy a jogi és nem jogi feltételek együttese hogyan befolyásolta az önkormányzatok döntéseit, milyen okokra vezethetők vissza a közszolgáltatások területén tapasztalható müködési zavarok. A tanulmány terjedelmi okok miatt azonban a gyakorlat bemutatásával és elemzésével már nem foglalkozik, annak ellenére, hogy véleményünk szerint az önkormányzatok alkalmasságának megítéléséhez erre is szükség van.

\section{A közszolgáltatási modell alapja²}

1.1. Minden közszolgáltatási modellnek több eleme van, melyek egymást kölcsönösen meghatározzák, befolyásolják ${ }^{3}$. A közszolgáltatás sajátos szolgáltatás, melynek megszervezését közérdek vagy egyének közös szükséglete indokolja. A közhatalom elsődleges feladata, hogy elfogadja, elismerje adott érdek, szükséglet „köz” jellegét. Az elismerés nemcsak formai, hanem tartalmi elismerést is jelent, azaz annak meghatározását, hogy mi az a szolgáltatás, amit közszolgáltatásként ismer el.

1.2. A közhatalom feladata az is, hogy a szolgáltatás nyújtásáért meghatározott felelösséget vállaljon, s megteremtse, biztosítsa a közszolgáltatás nyújtásához szükséges jogi feltételrendszert, így azt, hogy ki és milyen feltételek esetén lehet közszolgáltató. A szolgáltatás nyújtásáért való felelősségvállalás különböző formában jelenhet meg, melynek módja és mértéke függ attól, hogy a közhatalom milyen szerepet tölt be a szolgáltatás tényleges nyújtásában, finanszírozásában, milyen tulajdonosi

2 Uniós tagságunkból adódik, hogy egy szolgáltatás közszolgáltatáskénti elfogadásának elsődleges kereteit az EU határozza meg. Az Európai Unióról szóló szerződéshez (EUSZ) és az EU működéséről szóló szerződéshez (EUMSZ) csatolt 26. jegyzőkönyv alapján közös uniós érték az általános gazdasági érdekű szolgáltatások által kielégítendő igények, szükségletek sokfélesége, a tagország szabadsága a szükségletkielégítés módjának meghatározásában. A tagországok tehát szabadok annak meghatározásában, hogy milyen közszolgáltatási modellt alkalmaznak az EUMSZ 14. cikkében foglalt korlátok között. - Az Európai Unióról szóló szerződés és az Európai Unió müködéséről szóló szerződés egységes szerkezetbe foglalt változata (2010/C 83/01) HU 2010. 3. 30. Az Európai Unió Hivatalos Lapja C 83/1 (C83/308).

3 A közszolgáltatás megszervezésének modellezésével foglalkozik a közmenedzsment. (Lásd többek között: Horvátr M. Tamás: Helyi közszolgáltatások szervezése, Budapest-Pécs, Dialóg Campus Kiadó, 2002; Szolgáltatások (a harmadik évezredben), szerk. Papp Ilona, Aula Kiadó Kft., 2003; HoRvÁtH M. Tamás: Közmenedzsment, Budapest-Pécs, Dialóg Campus Kiadó, 2005; A közszolgáltatások szervezésének alternatívái, szerk. LÁszló Mária-PAP Norbert, Pécs, Lomart, 2007; HoffmAn István: Önkormányzati közszolgáltatások szervezése és igazgatása az elmélet és a gyakorlat tükrében, Budapest, ELTE Eötvös Kiadó, 2009; HoFFMAN István: Gondolatok a helyi önkormányzatok társulásairól. In: 20 éves a magyar önkormányzati rendszer, Pécsi Közigazgatás-tudományi közlemények 3. (A „Jövő Közigazgatásáért” Alapítvány, Pécs, 2011). 
viszonyt alakít ki a létesítmények, eszközök és a közszolgáltatást végző munkaszervezet vonatkozásában.

1.3. A közszolgáltatás igénybevételét magánjogi és közjogi eszközök egyaránt jellemezhetik. A közszolgáltatás alapvetően három szereplő között hoz létre magánjogi és/vagy közjogi jogviszonyt: a közhatalmi szereplö, a közszolgáltató és a közszolgáltatást igénybe vevő között. A közszolgáltatás az igénybe vevői közösség számára elsősorban jogosultságként jelenik meg, de megjelenhet kényszerként, kötelezettségként is, ha az igény nem az egyén szintjén fogalmazódik meg, vagy az adott egyéni szükséglet kielégítési módja ellentétes a közösséget alkotó egyének közös érdekével. Attól függően, hogy a szükséglet kielégítésének módjára milyen jogviszony a jellemző, illetve, hogy a közszolgáltatás finanszírozásának mi a forrása, magánjogi vagy közjogi modellröl beszélhetünk ${ }^{4}$.

1.4. A fentiek alapján a közszolgáltatás modellje megmutatja a közhatalmi (állami/ önkormányzati) szereplö, a közszolgáltató és a közszolgáltatást igénybe vevők közötti kapcsolatot, ideértve a szükséglet meghatározását és kielégítésének módját, a közszolgáltatás finanszírozását, valamint a közszolgáltató kiválasztását.

\section{A települési hulladékkezelési közszolgáltatás jogi hátterének modellek szerinti összegzése}

A modellek felvázolása elött először röviden ismertetjük, hogy a rendszerváltást követően hogyan alakult a szükséglet és igénybevételi módjának meghatározása, a tulajdonosi szerkezet, az ellátás nyújtásáért, valamint a közszolgáltatás finanszírozásáért való felelősség.

\subsection{A szükséglet és igénybevételi módjának meghatározása}

2.1.1. Az 1989-es rendszerváltást követően az önkormányzati törvény az önkormányzat nem kötelezően ellátandó feladatai között sorolta föl a köztisztasági és a településtisztasági feladat ellátását ${ }^{5}$. Az évek során a jogszabályi változások miatt e fogalmak tartalma folyamatosan változott, és a hulladékgazdálkodási törvény (2000. évi XLIII. tv., Hgt.) megjelenésével lényegében kiürült. A köztisztasági szolgáltatás és a településtisztasági szolgáltatás tartalmilag nem maradt szabályozatlanul, csak az új szabályozás más terminológiát használt.

4 HoRVÁTH a közjogi és magánjogi megkülönböztetést elsősorban az önkormányzat és a közszolgáltató viszonylatában vizsgálja. A német modell esetén kiemeli, hogy a kétféle munkaszervezeti megoldás közül az egyik a közjog, míg a másik a magánjog hatálya alá tartozik, így az irányításban alkalmazható eszközök is eltérnek egymástól. HoRvÁtH (2005): i. m., 61.

5 Az önkormányzati törvény kezdetben az önkormányzatok feladatai között csak a településtisztasági feladatot sorolta föl. (Lásd a helyi önkormányzatokról szóló 1990. évi LXV. törvény 8. § (1) szövegét kihirdetése napján) A köztisztasági feladat csak 1994-ben került a törvénybe. (1994. évi LXIII. tv. 3. § (1) egészítette ki.) Az önkormányzati törvény az akkor hatályos szabályozásnak (1/1986. (II. 21.) ÉVM-EüM r. 4/1984. (II. 1.) ÉVM r.) megfelelő fogalmakat vette át. 
2.1.2. A Hgt. a szilárd és a folyékony hulladékkezelésre létrehozta a települési hulladékkezelési közszolgáltatás fogalmát, míg a közterület tisztán tartására szervezett közszolgáltatást (amely kiterjed az elhagyott hulladékra is) külön nevesítette. A közszolgáltatások megszervezését az önkormányzatok számára kötelezővé tette, s döntésükre bízta, hogy díjat határoznak meg, vagy a közszolgáltatás ingyenességét állapítják meg. A Hgt. ezzel az önkormányzatok számára választási lehetőséget biztosított abban, hogy közjogi vagy magánjogi modellt alkalmaznak-e.

2.1.3. A két modell eltérő kapcsolatot hoz létre az önkormányzat, a közszolgáltató és az ingatlantulajdonos/használó (igénybe vevő) között. A közjogi modellben csak az önkormányzat áll szerződéses kapcsolatban a közszolgáltatóval, míg a közszolgáltató kapcsolata az igénybe vevővel abban merül ki, hogy elviszi a kihelyezett hulladékot. A közszolgáltatás fedezetét az önkormányzat saját forrásból, azaz többnyire adóbevételeiből biztosítja, ezért hívjuk ezt a rendszert közjogi modellnek.

A magánjogi rendszerben az önkormányzat és a közszolgáltató mellett megjelenik az igénybe vevő és a közszolgáltató közötti szerződés ${ }^{6}$ is, melynek következtében a szolgáltatásért járó ellenszolgáltatást már ő köteles fizetni, ezért nevezzük ezt magánjogi modellnek. Bár a magánjogi modellben is megjelenik közjogi elem azzal, hogy a díjhátralék adók módjára behajtható köztartozás, mégis a két modellben a közszolgáltató és az igénybe vevő közötti kapcsolat teljesen más lesz.

2.1.4. A Hgt. a közszolgáltatást igénybe vevői kört differenciáltan szabályozta. A Hgt. az ingatlan használatának (tulajdonos személye, használója, ingatlan fekvése) jellegére való tekintettel tett különbséget. A gazdálkodó szervezetek esetén a szabályozás - a hulladék termelőjére vonatkozó kötelezettségből kiindulva, települési hulladékuk vonatkozásában - a közszolgáltatáshoz való csatlakozást a gazdálkodó szervezetek döntésére bízta, azaz számukra elkerülhetővé tette; az üdülőingatlannal rendelkező tulajdonosok számára pedig arányosított (a lakóingatlanokhoz viszonyított) díj meghatározását írta elő.

2.1.5. A közszolgáltatás megszervezésére és részletes szabályozására - edényméret, gyakoriság stb. - a Hgt. az önkormányzatokat hatalmazta fel. Az önkormányzati rendeletalkotáskor figyelembe kellett venni az országos hatályú jogszabályokat

6 A közszolgáltató és az igénybe vevő közötti viszony szerződéses jellegét az Alkotmánybíróság mondta ki, amikor az ingatlantulajdonosok megtámadták azokat az önkormányzati rendeleteket, melyek a közszolgáltatást kötelezővé tették. Az Alkotmánybíróság megállapította, hogy a szilárd hulladékkezelési közszolgáltatás a Ptk. által szabályozott szerződéses viszony (közüzemi szerződés, Ptk. 387. §, 388. §), melynek szabályozására az önkormányzatnak nincs felhatalmazása, ezért megsemmisítette azt a tanácsi rendeletet, mely meghatározta a kizárólagos közszolgáltatót, az ingatlantulajdonost kötelezte a közszolgáltatás igénybevételére, és meghatározott összegű díj fizetésére, függetlenül attól, hogy keletkezett-e nála hulladék (szemét) vagy sem. A határozatban felhívta a figyelmet arra is, hogy az önkormányzati rendeletalkotás törvényi megalapozottsága esetén nincs akadálya annak, hogy a települési szilárd hulladékkezeléssel kapcsolatos szerződéses viszonyról az önkormányzatok rendelkezzenek. - 25/1994. (V. 10.) AB-hat. Az Alkotmánybírósághoz beadatott eredeti kezdeményezés (1131/B/1993. AB-hat.) 5 önkormányzat rendeletét érintette. $A z A B$ mindegyik kapcsán ugyanazt az érvelést alkalmazta, és megsemmisítette a szerződéses viszonyra vonatkozó önkormányzati rendelkezéseket. 39/1994. (VI. 30.) AB-hat., 40/1994. (VI. 30.) AB-hat., 41/1994. (VI. 30.) AB-hat., 43/1994. (VI. 30.) AB-hat. 
(nem lehettek azokkal ellentétesek, illetve nem rendezhettek olyan kérdést, melyet azok már rendeztek ${ }^{7}$ ).

2.1.6. A Hgt. által lehetővé tett kettős rendszer szabályozása mind országos, mind helyi szinten eltért. A magánjogi rendszer szükségessé tette az önkormányzat hatósági ármegállapító jogkörének biztosítását, a szerződéses viszonyra vonatkozó szabályok meghozatalát, melyeknek a közjogi rendszer esetén nincs jelentősége. A tartalmában ugyanazt a magatartást előíró jogszabály jogi megítélése más a magánjogi és más a közjogi rendszerben. Ugyanakkor a közjogi és a magánjogi szabályozás nagyon hasonlít egymásra, hiszen a hulladékkezelés egy olyan közszolgáltatás, aminek a megszervezése iránti igényt nem egyéni szükségletek, hanem az adott közösség érdeke hozza létre. Ezért a jogszabályok, különösen a helyi rendeletek, kötelező rendelkezéseket tartalmaznak. A közjogi rendszerben a rendelet kötelező előírásai az igénybe vevők számára kötelező magatartási normaként jelennek meg, míg magánjogi rendszerben a szerződéses szabadság korlátozásaként.

\subsection{Tulajdonosi szerkezet}

2.2.1. A közhatalom szerepvállalását és az általa alkalmazható eszközöket meghatározza, hogy a hulladékkezelési közszolgáltatáshoz szükséges - ingó és ingatlan - vagyontárgyak kinek a tulajdonában vannak.

2.2.2. Az önkormányzatok már a rendszerváltást követő első években is kaptak lehetőséget arra, hogy címzett és céltámogatási igényt nyújtsanak be települési szilárd és/vagy folyékony hulladéklerakók építésére, később a hazai támogatási források mellett megjelentek az uniós források is ${ }^{8}$. A támogatási feltételektől függően változott az önkormányzatok részvétele ${ }^{9}$ az új lerakók, illetve egyéb létesítmények (hulladékszigetek, -udvarok, komposztálók stb.) létesítésében, ami meghatározta a tulajdonviszonyokat is.

2.2.3. A közszolgáltatás nyújtásához szükséges müszaki feltételek megteremtésére - gyüjtőedényzetek, szállítójárművek beszerzésére - az önkormányzatok számára szintén megnyíltak a támogatási források. A források részben az önkormányzatokért, részben a környezetvédelemért felelős tárca kezelésében álltak rendelkezésre, illetve az állam az uniós támogatások felhasználására önálló intézményrendszert hozott létre.

7 Az Alkotmánybíróság döntései alapján megállapítható, hogy az önkormányzatok gyakran túllépték a Hgt. adta felhatalmazás keretét (pl. a települési hulladék fogalmát „pontosították”), vagy az országos szabályozással ellentétes helyi szabályokat hoztak (pl. ritkább ürítési gyakoriságot engedtek). - 44/2001. (XI. 17.) AB-hat., 27/2003. (V. 30.) AB-hat., 60/2006. (XI. 9.) AB-hat., 151/2010. (VII. 14.) AB-hat.

8 A címzett és céltámogatási rendszer már 1991-ben biztosított támogatást hulladéklerakók építésére. A hazai forrásokat az idő múltával az uniós források egészítették ki (PHARE, ISPA, Kohéziós Alap). Az évek során többféle tulajdonú lerakó létesült, jellemzően önkormányzati lerakók épültek, bár megjelentek a tisztán magántulajdonban lévők is.

9 A támogatásra való jogosultság folyamatosan változott, a méretgazdaságossági szempontok egyre nagyobb szerepet kaptak. A 10000 lakost kiszolgáló kistérségi lerakók helyett megjelentek a 20000 lakost kiszolgálók, míg mára a 100000 lakost kiszolgáló regionális lerakók a jellemzőek. 
2.2.4. A közszolgáltatást ellátó munkaszervezetek szabályozását a rendszerváltás lényegében nem érintette ${ }^{10}$. Az önkormányzatok a tevékenység ellátására megtartották közüzemi vállalataikat, vagy átalakították őket korlátolt felelősségü, illetve részvénytársasággá. Megjelentek a multinacionális cégek, amelyek önállóan kezdték meg tevékenységüket, vagy az önkormányzatokkal közösen vegyes vállalatot hoztak létre ${ }^{11}$.

2.2.5. A közszolgáltató kiválasztásának módját, azaz azt, hogy szükséges-e a közszolgáltatók közötti versenyeljárás lebonyolítása vagy sem, a közszolgáltató tulajdonosi szerkezetében meglévő önkormányzati érdekeltség mértéke határozta meg ${ }^{12}$. Többségi önkormányzati tulajdon esetén a közszolgáltató pályáztatási eljárás nélkül kijelölhető volt. Emiatt a közszolgáltató kiválasztásáról szóló rendelkezések közvetlenül hatottak az önkormányzatok és a magánvállalkozások kapcsolatára, alakították a közszolgáltatói munkaszervezet tulajdonosi körét ${ }^{13}$.

\subsection{Az ellátás nyújtásáért való felelősség}

2.3.1. A rendszerváltás nem érintette az önkormányzatok meglehetősen nagy szabadságát abban, hogy kire bízzák a közszolgáltatást. Az állam közvetlenül nem kötötte meg az önkormányzatok kezét abban, hogy milyen szervezeti vagy irányítási megoldást választanak a közszolgáltatás biztosítására. A közszolgáltató kiválasztási eljárásának szabályozását ugyanis nem tekintjük közvetlen beavatkozásnak.

2.3.2. A Hgt. az önkormányzatok összefogását nem tette kötelezővé. Egyrészt megengedte, hogy az önkormányzat már meglévő rendszerhez csatlakozzon, átadva ezzel a megszervezésért járó felelősséget, másrészt, hogy más önkormányzatokkal közös közszolgáltatót hozzon létre létesítmény üzemeltetésére vagy közszolgáltatás ellátására.

2.3.3. A közszolgáltatás ellátásának szervezeti megoldását részben közvetve, részben közvetlenül meghatározták a létesítmények - különösen a lerakók - megvalósí-

10 A Köztisztasági Egyesülés által készített tanulmány mellékletében szereplő közszolgáltatói névsor alapján megállapítható, hogy a mai napig megmaradt a közszolgáltatók jogi formabeli változatossága, annak ellenére, hogy számukban 2007 és 2010 között radikális változás következett be (780-ról 199-re csökkent). - A települési hulladék kezelésének jellemző költségviszonyai, a szolgáltatás gazdasági összefüggései a közszolgáltatók szemszögéből, közzéteszi a Köztisztasági Egyesülés (a tanulmány elérhetősége: http://www. kvvm.gov.hu/data/kiadvanyok/kvvm_kiadvany_15.pdf).

11 A közmenedzsment egyik kulcskérdése, hogy az állam/önkormányzat milyen viszonyt hoz létre a különböző típusú közszolgáltatóval.

12 Hgt. 25. §, 3. § d), 4-5. §; 21/2000. (XII. 23.) Korm. r.

13 A Köztisztasági Egyesülés igazgatójának, Nagy Györgynek a szóbeli tájékoztatása szerint 2011 augusztusában 70 közszolgáltatót vizsgálva a magánérdekeltség 31 közszolgáltatónál volt jelen, ez a közszolgáltatók 44\%-a. Ha a lakossági létszámot nézzük (7252301 fö) akkor az arány hasonló, a magánérdekeltséggel is bíró közszolgáltatók a lakosság 47\%-át látják el. Ugyanakkor, ha e közszolgáltatók által ellátott települések számát nézzük (2099 db), akkor ez az arány már jelentős mértékben megváltozik, a magánérdekeltséggel is bíró közszolgáltatók ugyanis a települések 74 százalékán biztosítják a közszolgáltatást. 
tásához nyújtott pályázati források. A pályázati feltételek alapján - különösen az uniós források esetén - szükségessé vált az önkormányzatok társulása ${ }^{14}$.

2.3.4. A fenti megoldások a független önkormányzatok mellett különbözőképpen hoztak létre regionális rendszereket. Egyrészt a közszolgáltatás megszervezésének alapegységét, az önkormányzatokat a közszolgáltatók vagy maguk az önkormányzatok a társuláson keresztül kisebb-nagyobb területre kiterjedő közszolgáltatási területté fejleszthették. Másrészt a pályázatok miatt a közszolgáltatás megszervezésének nemcsak az egyes önkormányzat lett az alapegysége, hanem a regionális lerakók köré szerveződő önkormányzatok összessége is ${ }^{15}$.

\subsection{A közszolgáltatás finanszírozásáért való felelősség}

\section{A költségmegosztás}

2.4.1. A Hgt. a tevékenység finanszírozását a közszolgáltatáson keresztül biztosította, s a tehermegosztást a helyi szabályozástól tette függővé, azaz attól, hogy az önkormányzat magánjogi vagy közjogi modellt választ. Ahol a közszolgáltatás igénybevételét az önkormányzat díjhoz kötötte, ott a közvetlen költségviselö az igénybe vevő lett, míg ott, ahol a közjogi rendszert alkalmazták, a közvetlen költségviselővé az önkormányzat vált.

2.4.2. A közjogi modellben ennek az a következménye, hogy a közszolgáltatás költségeit az önkormányzat saját költségvetéséből fedezi. A helyi adókról szóló törvény szabályozza a kommunális adót, és annak kivethető legmagasabb mértékét is meghatározza ${ }^{16}$, így a közjogi modellben az önkormányzatok adóbevételen keresztüli forrásteremtése nem a közszolgáltatási feladatok költségeihez, hanem az állami korlátozáshoz igazodik.

2.4.3. A közszolgáltatás közjogi finanszírozásával az önkormányzat a közszolgáltatás költségviselését elválasztja a tényleges igénybevételtől. A közszolgáltatást igénybevevők és az azt ténylegesen - bár közvetve - finanszírozók (helyi adófizetők ${ }^{17}$ ) nem feltétlenül azonosak, hiszen a kommunális adó fizetési kötelezettség az ingatlantulajdonhoz kapcsolódik, míg a közszolgáltatást nem csak a tulajdonos veheti igénybe.

2.4.4 A Hgt. a magánjogi modellben a költségviselést megosztotta az igénybe vevők és az állam között azáltal, hogy olyan rendszert alakított ki, mely biztosítani kívánta, hogy a közszolgáltató költségeinek fedezetéhez, a dijhoz mindenképpen

14 A társulás regionális hulladéklerakók megépítéséhez kötelező feltétel volt. Az ISPA projektek pénzügyi megállapodásainak kihirdetéséről szóló kormányrendeletben már az előleg második részének kifizetéséhez is több esetben feltételként kötötték ki, hogy az érintett önkormányzatok a konzorciumi szerződést aláírják. - Egyes ISPA projektek pénzügyi megállapodásainak kihirdetéséről szóló 89/2004. (IV. 20.) Korm. r. 14. melléklet 8. cikk 3. b), 15. melléklet 8. cikk. 3. b), 16. melléklet 8. cikk 3. b) pont.

15 A regionális rendszerek kialakulását jól érzékeltetik a Köztisztasági Egyesülés által készített ábrák, amelyek térképen mutatják be azt, hogy az egyes településeken kik a közszolgáltatók. - Köztisztasági Egyesülés: i. m., 12-30.

16 A kivethető kommunális adó mértéke 1996 óta változatlan összeg (12000 Ft).

17 A helyi költségvetéshez való hozzájárulást a központi és helyi adószabályok határozzák meg. (Az 1990. évi C. tv. helyi adókról szóló törvény.) 
hozzájusson. A díjfizetés az igénybe vevő kötelezettsége volt, de az állam quasi „fedezeti garanciát” vállalt a nem fizető igénybe vevőkért.

2.4.5. A díjhátralékot a közszolgáltató azonban nem közvetlenül az államtól, hanem az önkormányzattól igényelhette. Ennek elsődleges oka, hogy az adók módjára behajtható köztartozásnak minősített díjhátralék behajtását a jegyző hatáskörébe utalta, s az állami „fedezeti garancia” csak a behajthatatlan díjhátralékra vonatkozott. Az állami „fedezeti garancia” közvetett jellege miatt az önkormányzat mintegy megelölegezte a behajthatatlan díjhátralékot. A díjhátralék behajtásával kapcsolatos eljárási szabályok miatt a költségek teherviselői közé a magánjogi rendszerben is bekerült az önkormányzat.

\section{Pénzügyi kockázatviselés}

2.4.6. A költségviselés megosztása mellett szólni kell a pénzügyi kockázat viseléséről is. A szerződéses idő alatti költségnövekedés pénzügyi kockázatának viselése függ a finanszírozás elveitől, módszereitől, így a díjtól, a díj meghatározásának elveitől. A Hgt. alapján kiadott kormányrendelet kötelezte a közszolgáltatót és az önkormányzatot, hogy egymás közti szerződésükben mindezeket rendezzék ${ }^{18}$.

2.4.7. A Hgt. és a végrehajtására kiadott kormányrendelet olyan díj megállapítását írta elő, mely a közszolgáltató költségeit fedezi. A részletes szabályokról szóló kormányrendelet ${ }^{19}$ a közszolgáltató kötelességévé tette a díjmegállapításhoz szükséges - a részletes szakmai szabályoknak megfelelö - díjkalkuláció elkészítését. A kormányrendelet azt is rögzítette, hogy az önkormányzat köteles a közszolgáltatónak díjkompenzációt fizetni, amennyiben rendeletében a költségeket nem fedező, azaz a díjkalkulációnál alacsonyabb díjat állapítana meg. Ez azt jelenti, hogy amennyiben a költségnövekedést az önkormányzat a díjakban nem érvényesíti, akkor annak fedezetét neki kell biztosítania, azaz a közszolgáltatás költségnövekedésével járó pénzügyi kockázatviselő az önkormányzat lett.

2.4.8. A Hgt. lehetővé tette azt is, hogy az önkormányzat díjkedvezményt határozzon meg. A díjkedvezmény összegét a közszolgáltatónak az önkormányzat köteles megfizetni. A díjkompenzáció és a díjkedvezmény intézménye a tisztán magánjogi, illetve tisztán közjogi modell mellett lehetővé tette a vegyes modell működtetését, mely az önkormányzat döntésétől függően a költségviselést megosztotta az igénybe vevők és az önkormányzat között.

2.4.9. A három modell közötti választás három különböző finanszírozási elv és módszer alkalmazhatóságát hozta létre. Az elvek és módszerek változtatásának lehetőségét és/vagy módját szabályozó eszköz a közszolgáltató és az önkormányzat közötti szerződés lett.

\section{Fejlesztések finanszírozása}

2.5.1. A Hgt. lehetőséget adott arra, hogy az önkormányzat külön szerződést kössön a hulladék gyűjtésére és szállítására, illetve az ártalmatlanításra. Az ártalmatlanítás esetén a szerződés legrövidebb időtartama 10 év, míg a gyűjtés, szállítás ese-

18 241/2000. (XII. 23.) Korm. r. 30. §; 224/2004. (VII. 22.) Korm. r. 13. §.

19 242/2000. (XII. 23.) Korm. r., majd később a 64/2008 (III. 24.) Korm. r. 
tén a leghosszabb 10 év ${ }^{20}$. Fontos kérdés tehát, hogy a több évre szóló szerződések alatt szükségessé váló fejlesztések finanszírozása hogyan alakul.

2.5.2. A Hgt. a fejlesztésekröl külön nem rendelkezett, így a közszolgáltatások fejlesztése négy különböző szintủ kezdeményezésre, illetve finanszírozásra épülhet. A közszolgáltatás fejlesztését kezdeményezheti és finanszírozhatja a közszolgáltató, $s$ a fejlesztés költségnövelő hatásának érvényesítése függ attól, hogy azt az önkormányzat elfogadja vagy sem. A közszolgáltató fejlesztési kezdeményezésének több oka is lehet: a közszolgáltatóra vonatkozó jogszabályi, hatósági változás, vagy a szükséglet mennyiségi, minőségi változása. A közszolgáltató jogszabályon vagy hatósági határozaton alapuló kötelező fejlesztése olyan költségnövekedés, mely a tevékenység jogszerủ végzéséhez szükséges, így azt az önkormányzat a díjképzési elvek miatt köteles elfogadni, míg a közszolgáltató saját kezdeményezésủ - nem kötelező - fejlesztését már nem köteles elfogadni, mert a szükségletet és kielégítésének módját az önkormányzat határozhatja meg. A magánjogi modellben a költségnövekedés elfogadása díjemelést eredményez, míg a közjogi rendszerben esetleg adónövekedést, vegyes a rendszerben pedig az önkormányzat döntésétöl függ, hogy melyiket emeli.

2.5.3. Önkormányzati kezdeményezésre és/vagy finanszírozásra támaszkodó fejlesztés esetén a feltételeket az önkormányzat alakítja, és az önkormányzat a modelltől függően veszi figyelembe a fejlesztés miatt bekövetkező költségváltozásokat.

2.5.4. Az állami kezdeményezésre és/vagy finanszírozásra támaszkodó fejlesztés az önkormányzatitól abban különbözik, hogy a támogatás címzettje lehet egy, vagy egyszerre több önkormányzat is. A feltételeket az állam határozza meg, és a fejlesztés miatt bekövetkező költségváltozásokat az önkormányzat vagy az önkormányzatok külön-külön, saját modelljüktöl függően veszik figyelembe.

2.5.5. Az uniós pályázatok az előzőektől két szempontból eltérnek, egyrészt a támogatást egy - adott önkormányzatok által létrehozott - közösség kapja, másrészt a pályázatban kötelező bemutatni nemcsak a fejlesztés költségvonzatát, hanem azt is, hogy a pályázó hogyan fogja beépíteni meglévő rendszerébe az új eszközök, létesítmények müködtetési költségét. A támogatási szerződést, a társulási megállapodást aláíró önkormányzatok kötelezettséget vállalnak arra, hogy a megvalósuló fejlesztést a pályázatban leírtaknak megfelelően meghatározott ideig müködtetni fogják ${ }^{21}$.

2.5.6. A hazai pályázati források igénylésekor, több önkormányzat részvétele esetén, az önkormányzatok szabadon egyezkedhetnek a müködési költségek viseléséröl a fejlesztést követően, s ha úgy tartják jónak, a fejlesztés szabad kapacitását más javára is hasznosíthatják. Az uniós fejlesztés esetén az önkormányzatok egy személyként vállalják a müködtetési költségeket, s annak viselési módját - a várható dijat - is rögzítik. Ez azt jelenti, hogy ha az uniós pályázatot úgy készítették elö, hogy nem vették figyelembe az önkormányzati modellek közötti különbséget, akkor a támogatás elnyerése az önkormányzatok modellválasztási szabadságát korlátozhatja.

20 Hgt. 28. § (2) és (3) bek.

21 L. többek között az ISPA-támogatással megépülő regionális hulladékgazdálkodási rendszerek pénzügyi támogatásáról szóló megállapodásokat (2000/HU/16/P/PE/006, 2001/HU/16/P/PE/008, 2001/HU/16/P/ PE/010, 2002/HU/16/P/PE/014, 2002/HU/16/P/PE/015, 2002/HU/16/P/PE/016, 2002/HU/16/P/PE/017, 2002/HU/16/P/PE/018) a kihirdető kormányrendeletben - 89/2004. (IV. 20.) Korm. r. 
2.5.7. A lerakó megépítésére elnyert uniós pályázatok részben közvetlenül, részben közvetve az önkormányzatok közszolgáltató kiválasztási és díjmegállapítói jogát is korlátozzák azáltal, hogy a társult önkormányzatok a pályázat alapján társulási megállapodásban vállalták, hogy települési hulladékukat az új lerakóba szállítják, a lerakó üzemeltetésével járó költséget a díjba beépítik, valamint gyűjtésre, szállításra új közszolgáltatási szerződést a társulás által létrehozott közszolgáltatóval kötnek, a társulás által meghatározott díjképzési elvek szerint ${ }^{22}$.

\section{Modellek a szabályozás alapján}

3.1. Az alábbi ábrák a Hgt. által bevezetett - közjogi, magánjogi és vegyes - modelleket vázolják föl, az elemeket ért jelentős változások előtt. Az I. fejezet elméleti vázlatának megfelelően a modellek három fő elemből állnak: a közszolgáltató kiválasztása, a szükséglet és kielégítési módjának meghatározása, illetve a közszolgáltatás finanszírozása. Ez utóbbinál a modellben megjelenik az is, hogy a kiválasztás eljárási szabályait a jogalkotó a közszolgáltató tulajdonosi szerkezetétől függően kétféleképpen alakította. (A három elemhez való tartozást színekkel jelöltük.)

\section{A közjogi modell 2004 elött $^{\star}$}

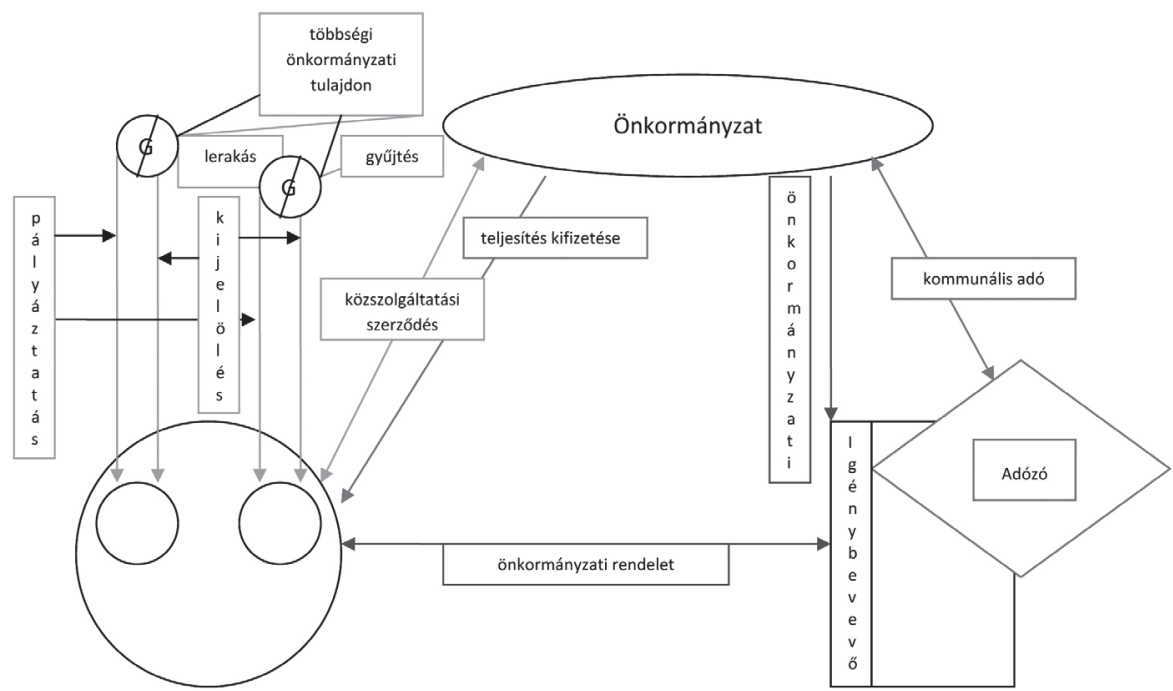

* A „G” a megfelelő engedéllyel rendelkező gazdálkodó szervezetet jelöli. A színek a modellen belüli elemeket jelölik: sárga - a közszolgáltató kiválasztása; zöld - a szükséglet meghatározása; lila - a finanszírozás. Az önkormányzat és a közszolgáltató közötti szerződés az ábrán ugyan sárga, de mindegyik területre vonatkozó megállapodást tartalmaz. (A színek nyomtatásban a megfelelő árnyalatokkal azonosíthatók - a szerk.)

22 Az önkormányzatok szabadságukat önkéntesen korlátozták a közösségi támogatásra benyújtott pályázati dokumentációban. A szabadság korlátozásának mértéke jól érzékelhető a pénzügyi megállapodásokban, melyek tartalmazzák a pályázatok leglényegesebb részeit is. (Lásd: a 21. lábjegyzetben felsorolt pénzügyi megállapodásokat.) 


\section{A magánjogi modell 2004 előtt}

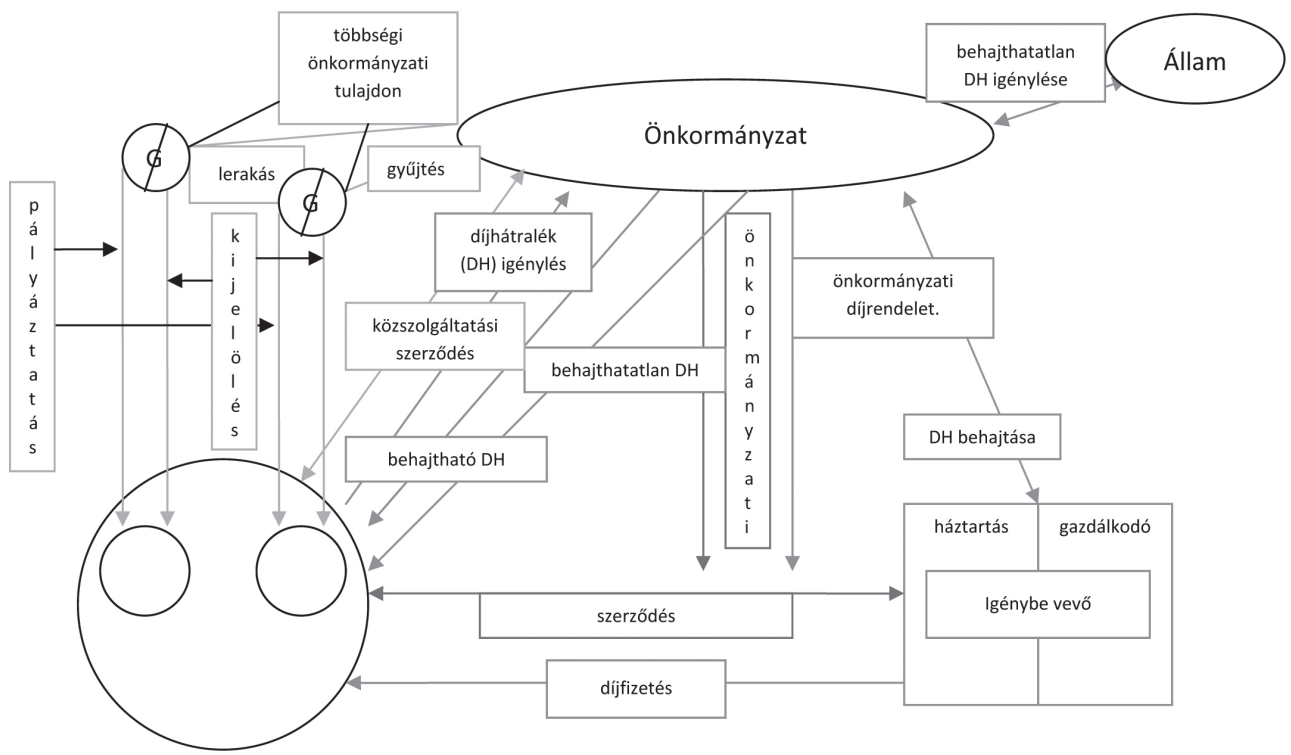

\section{A vegyes modell 2004 elött}

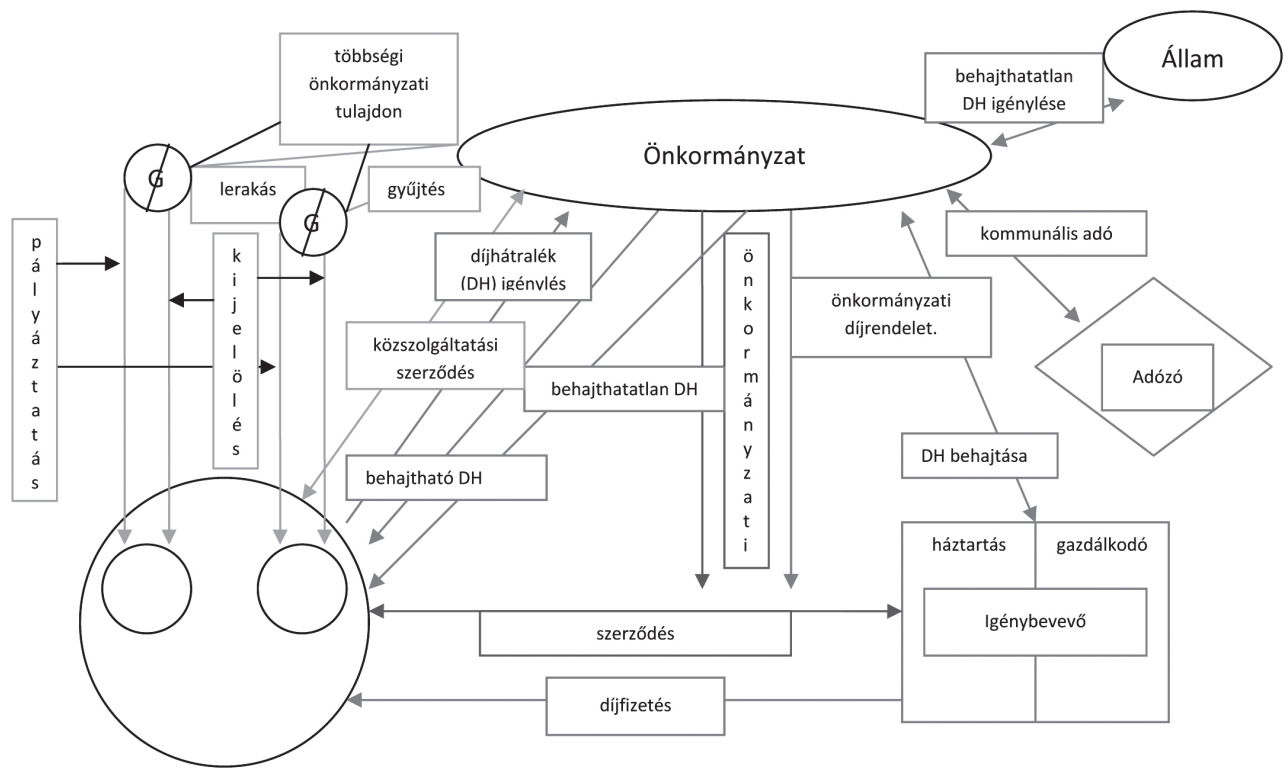

3.2. A Hgt. a három modellt külön nem nevesítette, és nem is különböztette meg egymástól, annak ellenére, hogy köztük lényeges különbség van. A szükséglet meghatározása és annak kielégítési módja a három modellben más kapcsolatrendszert hoz létre a közszolgáltató, az igénybe vevő és az önkormányzat között. A szükséglet 
meghatározása mindhárom modellben az önkormányzati rendeleten keresztül történik, de míg a közjogi modellben az önkormányzati rendelet közvetlenül határozza meg az igénybe vevő magatartását, addig a magánjogi és vegyes rendszerben hatása közvetett, az önkormányzati rendelet rendelkezései a közszolgáltató és az igénybe vevő közötti szerződésen keresztül, mint annak kötelező tartalmi elemei hatnak. $E$ különbséget tükrözi az önkormányzat és a közszolgáltató közötti szerződés is.

3.3. A három modellben jellegét tekintve kétféle tartalmú szerződés születik az önkormányzat és a közszolgáltató között. A magánjogi és vegyes modellben a köztük létrejövő szerződésben rendezik mindazokat a kérdéseket is, melyek az önkormányzati rendelet alapján a közszolgáltató és az igénybe vevő közötti szerződéses viszony teljesítéséhez szükségesek. A közjogi rendszerben az igénybe vevők mint a közszolgáltató és az önkormányzat közötti szerződés kedvezményezettjei szerepelnek, s ennek megfelelően alakul a szerződés tartalma is.

3.4. A finanszírozási kérdések is modellfüggőek. A közjogi modellben az állam nem vállal szerepet a müködés finanszírozásában, az csak a másik két modellben jelenik meg. Mégis a közszolgáltatók számára a közjogi és a magánjogi rendszer lényegében azonos pénzügyi kockázatot jelent. Bár a magánjogi rendszerben az elsődleges díjfizető az igénybe vevő, az állami háttérfelelősség és az önkormányzatokat terhelő fizetési kötelezettség a közszolgáltató számára közel azonos pénzügyi helyzetet teremt, mint a közjogi rendszer. Állami finanszírozás mellett kettőjük szerződésében nincs szükség a finanszírozási kérdések rendezésére, mert azt a Hgt. megtette.

3.5. A költségek elismerésével, megtérítésével kapcsolatos közhatalmi szerep is modellfüggő. Az önkormányzat hatósági ármegállapító ${ }^{23}$. E szerepet azonban csak a magánjogi és a vegyes rendszerben tölti be. A magánjogi rendszerben a feladata, hogy a költségek ismeretében értékelje (fogadja el vagy utasítsa el) a közszolgáltató javaslatát és határozza meg a díjat. Közhatalmi tevékenysége kettős: minősíti a közszolgáltató költségeit, és meghatározza az igénybe vevők közötti költségmegosztást. A Hgt. végrehajtására kiadott kormányrendelet a díjmegállapítói jogkör két oldalát eltérően ítéli meg, és nem az egészet, hanem csak az igénybe vevők felé történő díjmeghatározást tekinti közhatalmi aktusnak, míg a közszolgáltató felé - „alacsonyabb" ár - esetén díjkompenzációs kötelezettséget ír elő, valószínüsíthetően az önkormányzat és a közszolgáltató közötti szerződéses kapcsolatra tekintettel. Ebből a kettősségből adódik, hogy a díjat az igénybe vevők a kihirdetés jogi formája miatt (önkormányzati rendelet) az Alkotmánybíróság előtt támadhatják meg, míg a díjkompenzáció elmaradása miatti vita szerződéses vitává válik, és a bírósághoz fordulhatnak a felek.

A díjat és annak meghatározását az Alkotmánybíróság csak alkotmányossági szempontból értékelheti az önkormányzat és az igénybe vevők viszonyában, míg a bíróság azt a polgári jogi szerződésekre vonatkozó szabályok szerint - szakértő bevonásával - az önkormányzat és a közszolgáltató közötti viszonylatban vizsgálja.

23 HoRvÁTH az önkormányzati hatáskör kapcsán megfontolandónak tartja szigorúbb jogszabályi garanciák beépítését a költségarányos ártól való eltérés korlátozására, illetve a közszolgáltató ajánlatának kontrolljára. - HORVÁtH (2005): i.m. 104. 
Mivel a Hgt. végrehajtására kiadott kormányrendelet csak részben ismeri el az önkormányzat hatósági díjmegállapító jogát mint közhatalmi jogosítványt, ezért a dijnak és megalapozottságának a felülvizsgálatára nincs olyan hatáskörrel rendelkező szervezet, mely döntését egységes szakmai elvek alapján, a közhatalmi jogosítvány mindkét oldalát egyszerre, egy eljárás keretében mérlegelve hozhatná meg.

3.6. Az önkormányzat és a közszolgáltató közötti közszolgáltatási szerződésre vonatkozó kormányrendelet ezt a „féloldalas” közhatalmi jogosultságot is korlátozza azzal, hogy a felek között létrejövő szerződés kötelező tartalmi elemévé tette a díjmeghatározás elveit és módszerét, változtatási lehetőségét ${ }^{24}$. Az önkormányzatot magánjogi szerződéses kötelezettsége köti a hatósági díjmegállapítás során. Ebből következik, hogy tulajdonképpen a díjmegállapító önkormányzati rendelet nem más, mint egy magánjogi szerződés jogszabályi rangra emelése. Bár a magánjogi szerződés magát a díj összegét csak a szerződéskötéskor rögzíti, mégis a későbbi díjat a magánjogi szerződés alapján fogják meghatározni. A kormányrendelet a díjmegállapítás szabályait jogszabály helyett a felekre bízza, akik azt egy magánjogi szerződésben rögzítik.

3.7. Az önkormányzat a közjogi modellben adómegállapító szerepet tölt be, ahol a kivetett adó (kommunális adó) és a közszolgáltató költségeinek önkormányzati elismerése között nincsen látható kapcsolat. Az önkormányzat tisztán magánjogi szerződéses viszonyt alakít ki a közszolgáltatóval, és tisztán közjogi viszonyt az igénybe vevővel. Az első viszonyban a költségelismerés kérdése két egyenrangú fél közötti szerződéses viszony része, melynek nincsen köze közhatalmi jogosítványhoz, míg a második viszonyban adott önkormányzati feladatellátás költségeinek adózók közötti tehermegosztásáról van szó, mely adózói közösség nem feltétlenül azonos az igénybe vevők közösségével, mint ahogy erről korábban már szó volt.

3.8. A vegyes rendszerben az önkormányzat mindkét szerepet egyszerre tölti be. A vegyes rendszer választása az önkormányzat szabad döntése, bár adódhat olyan helyzet, mely kényszerítő hatású. Arra már utaltunk, hogy adómegállapítói jogát a központi szabályozás korlátozza, így az adó mértékét nem igazíthatja a költségekhez. Ha a költségek növekedése meghaladja a kivethető adó mértékét, az önkormányzat kényszerülhet arra, hogy egyszerre vessen ki adót, és állapítson meg díjat.

3.9. A vegyes rendszerben a díj nemcsak az igénybe vevők közötti költségviselést határozza meg, hanem az önkormányzat és az igénybevevők egésze/egyes csoportja közötti költségviselést is. Fontosnak tartjuk kiemelni, hogy a dijkompenzáció fizetésének elutasítása nem azonos az önkormányzatra - a vállalt költségviselési teherből - jutó összeg (pl.: kedvezmények) megfizetésének elmaradásával. A kettő abban

24 „A közszolgáltatási szerződés tartalmazza a közszolgáltatás díjának megállapítására vonatkozó módszer leírását, a díjnak a szerződés megkötésekor érvényesíthető legmagasabb mértékét és a díj megváltoztatása érdekében alkalmazandó eljárást." - 241/2000. (XII. 23.) Korm. r. 30. § (3). Hasonló megfogalmazást tartalmaz a 2004-es szabályozás is. Ezzel összhangban áll HoRvÁtH álláspontja, amikor a közigazgatási szerződések közös szabályait ismertetve a szerződés tartalmáról azt írja, hogy a fogyasztói díj „megállapítása történhet jogszabályban (önkormányzati rendeletben.) Szerződésre ebből annyi tartozik, hogy a dijmegállapítás javaslata meghatározott, és a szerződésben szabályozott alku eredménye.”- HoRVÁTH, (2005): i. m. 129. 
különbözik egymástól, hogy az első az önkormányzat közszolgáltatói javaslatról született „féloldalas” közhatalmi döntésének eredménye, míg a második az igénybe vevőktöl átvállalt költségviselési ígéret be nem tartásának következménye.

3.10. A vegyes rendszerben az önkormányzat az igénybe vevők felé egyszerre két különböző közhatalmi döntést hoz, az egyik megegyezik a magánjogi rendszerben, míg a másik a közjogi rendszerben hozottal. Az első döntés az igénybe vevői kör között hoz létre költségviselői közösséget, míg a másik az adózók között, s a két döntés a két közösséget összekapcsolja anélkül, hogy tudnának róla. Az első döntésben van értékelhető és látható kapcsolat a közszolgáltatás és költségviselés között, míg a második esetben nincs, akkor sem, ha a vegyes rendszert az önkormányzat azért választotta, mert az adóbevételek már nem fedezték az elismerhető költségeket. Az első döntés a közszolgáltatásra hivatkozva megtámadható az AB előtt, a második döntés nem.

3.11. A modellek nem adnak információt a regionális rendszerekröl, mivel a Hgt. csak önkormányzati szinten foglalkozott a közszolgáltatás nyújtásával, a regionális rendszerek kialakításában az önkormányzatok számára teljes szabadságot adott.

\section{A modellek jogszabályi módosítása}

\subsection{Pályáztatás helyett közbeszerzési eljárás}

4.1.1. 2004-ben a meglévő rendszerhez való csatlakozás lehetőségét hatályon kívül helyezték, s a közszolgáltató kiválasztására vonatkozó szabályozást a közösségi jogra való hivatkozással megváltoztatták ${ }^{25}$, így a közszolgáltató kijelölésére már csak akkor vált lehetöség, ha a közszolgáltató 100\%-ban önkormányzati tulajdonban volt, valamint nettó árbevételének 90\%-a az önkormányzattal kötött szerződésből származott ${ }^{26}$.

4.1.2. A jogszabályi módosítás a modelleket azonos módon érintette. A közszolgáltató kiválasztása független a modell jellegétöl, ezért szabályozása modellsemleges. Ugyanakkor megjegyzendő, hogy a 90\%-os szabályt az egységes jogértelmezés érdekében többször is módosítani kellett. A bevétel jelentésének pontosítása a hulladékkezelés területére értelmezve azt jelentette, hogy a 90\% számításakor azonos módon kellett figyelembe venni a közjogi és/vagy a magánjogi modellből származó bevételt.

4.1.3. Az eljárási szabályok módosulása ugyanakkor a korábbiakhoz képest más érdekeltségi viszonyt hozott létre az önkormányzatok és a magánbefektetők között. Az új szabály óta egy adott önkormányzat már nem egyértelműen érdekelt abban, hogy magánbefektetővel hozzon létre közös gazdálkodó szervezetet, hiszen közszolgáltatói szerződést közbeszerzési eljárás nélkül vele már nem tud kötni. A magánbefektetőnek szintén nem feltétlenül áll érdekében az önkormányzattal közös közszol-

25 2004. évi XCVII. tv. 3.§.

26 2003. CXXIX. tv. 2/A.§ (1) bek. 
gáltató létrehozása, mert ezen keresztül már nem tud verseny nélkül piachoz jutni. A közszolgáltató kijelölésének szabályozása - a verseny nélküli piacnyerés lehetöségétöl függően - közvetlenül befolyásolja az önkormányzat-magánvállalkozás kapcsolatát, együttmüködésük módját.

4.1.4. A hulladékkezeléssel foglalkozó közszolgáltatókat a fenti szabályozások, illetve a változások eltérő módon érintették. Azokat a közszolgáltatókat, illetve önkormányzatokat, amelyek 2004 előtt 10 éves szerződést kötöttek, a jogszabályi változás nem igazán érintette. Emiatt a jogi háttér változása átmenetileg az önkormányzatok és a magánszféra kapcsolatában két különbözö, egymással részben ellentétes, de meghatározott ideig együtt létező érdekeltségi rendszert teremtett. Az átmeneti időszak tartama a közszolgáltatók és az önkormányzatok között létrejött szerződések lejártától függ, s a Hgt. által 2000-ben kialakított érdekeltségi rendszer fokozatosan szünik meg, átalakítva ezzel az önkormányzatok és a magánszféra együttmüködését.

4.1.2. A szabályozás változása a regionális rendszerek alakulását is befolyásolta. A 90\%-os szabály az egyes gazdálkodó szervezetek közszolgáltatási piacának földrajzi területi megoszlására hatott, míg a csatlakozási lehetőség megszüntetése az önkormányzatok társulásait változtatta meg.

\subsection{Az állami „fedezeti garancia” megszüntetése}

4.2.1. A következő jelentős módosításra 2005 végén került sor. Az állam a behajthatatlan dijhhátralék megfizetéséhez támogatást sosem biztosított ${ }^{26}$, és 2005 . december 30-ai hatállyal az állami „fedezeti garanciára” vonatkozó rendelkezést hatályon kívül helyezte, maga helyett az ingatlantulajdonost (vagyonkezelőt) téve felelőssé a behajthatatlan díjhátralékért. A költségviselő 2005. december 30-ig az igénybe vevő és az állam helyett az önkormányzat, míg 2006-tól az igénybe vevő és az ingatlantulajdonos lett.

4.2.2. A módosítás megváltoztatta a pénzügyi kockázatviselés rendjét és a kockázatviselők személyét. 2006-tól a magánjogi és a vegyes rendszerben a nem fizetők miatti pénzügyi kockázatviselö - az állam/önkormányzat helyett - a közszolgáltató lett.

4.2.3. Az állami finanszírozási fedezet hiánya és lehetőségének megszüntetése felértékeli az önkormányzatok modellek közötti választási szabadságát. Mivel a három modell finanszírozási elve eltér egymástól, ezért megnövekszik az önkormányzat és a közszolgáltató közötti szerződés súlya. A jogszabályi változás a közszolgáltatók és

26 Ezzel ellentétes álláspontot képviselt az Alkotmánybíróság abban a határozatában, melyben a központi költségvetési fedezet hiánya miatt mulasztásos alkotmánysértés megállapítását kezdeményező beadványról döntött. Az AB álláspontja szerint az állam eleget tett a Hgt.-ben vállalt kötelezettségének azáltal, hogy költségvetésében a települési közszolgáltatással kapcsolatos támogatásokat biztosított. - 35/2004. (X. 6.) ABhat. $\mathrm{Az} A B$ által hivatkozott támogatások azonban nem a behajthatatlan díjhátralék fedezetére szolgáltak, hanem egyrészt a lakossági folyékony hulladék ártalmatlanítására, mely támogatás lehívásához bizonyítani kellett az ártalmatlanított folyékony hulladék mennyiségét, másrészt a települési közszolgáltatás fejlesztésére. A támogatások kötöttsége miatt az önkormányzatok azokat nem fordíthatták a szilárd hulladékkezelés behajthatatlan díjhátralékának fedezetére. 
az önkormányzat kapcsolatára a szerződések keletkezési időpontjától függően eltérően hathat. A közszolgáltató érdekévé válik, hogy a szerződésben megjelenjenek a pénzügyi kockázatviselésre, valamint a modellváltásra vonatkozó szabályok. Az önkormányzat ezzel szemben a modellváltás teljes szabadságának megőrzésében érdekelt, hiszen a korábbiakkal ellentétben a tisztán magánjogi rendszer bevezetésével akár teljes mértékben megszabadulhat a mögöttes költségviselési és pénzügyi kockázatviselési felelősségtöl. Ezen nem változtat az sem, hogy a díjhátralékot továbbra is adók módjára kell behajtani, mert ez a szabály a Hgt. megszületése óta megvolt.

\subsection{A modellek változása a módosítások hatására}

4.3.1. Az alábbi ábrák mutatják, hogy a két módosítás hogyan változtatta meg a három modellt. A korábbi ábrákkal is összevetve jól látható, hogy részben megváltoztak a modell szereplöi, részben megváltoztak a szereplök közötti kapcsolatok. Az ábra nem tudja érzékeltetni azt, hogy a jogszabályi módosítások a látszólag változatlan kapcsolatokat sem hagyták érintetlenül, mint ahogy azt az előző pontokban érzékeltettük.

\section{Közjogi modell 2005 után}

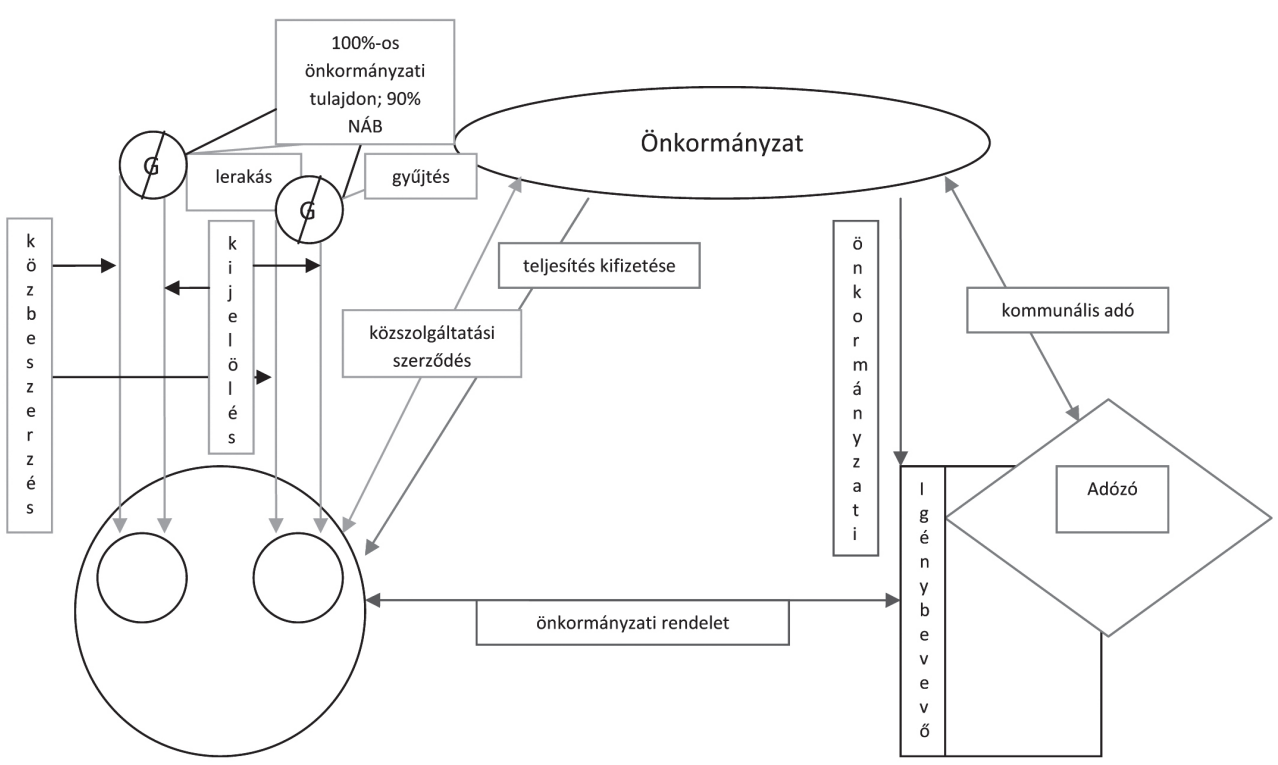




\section{Magánjogi modell 2005 után}

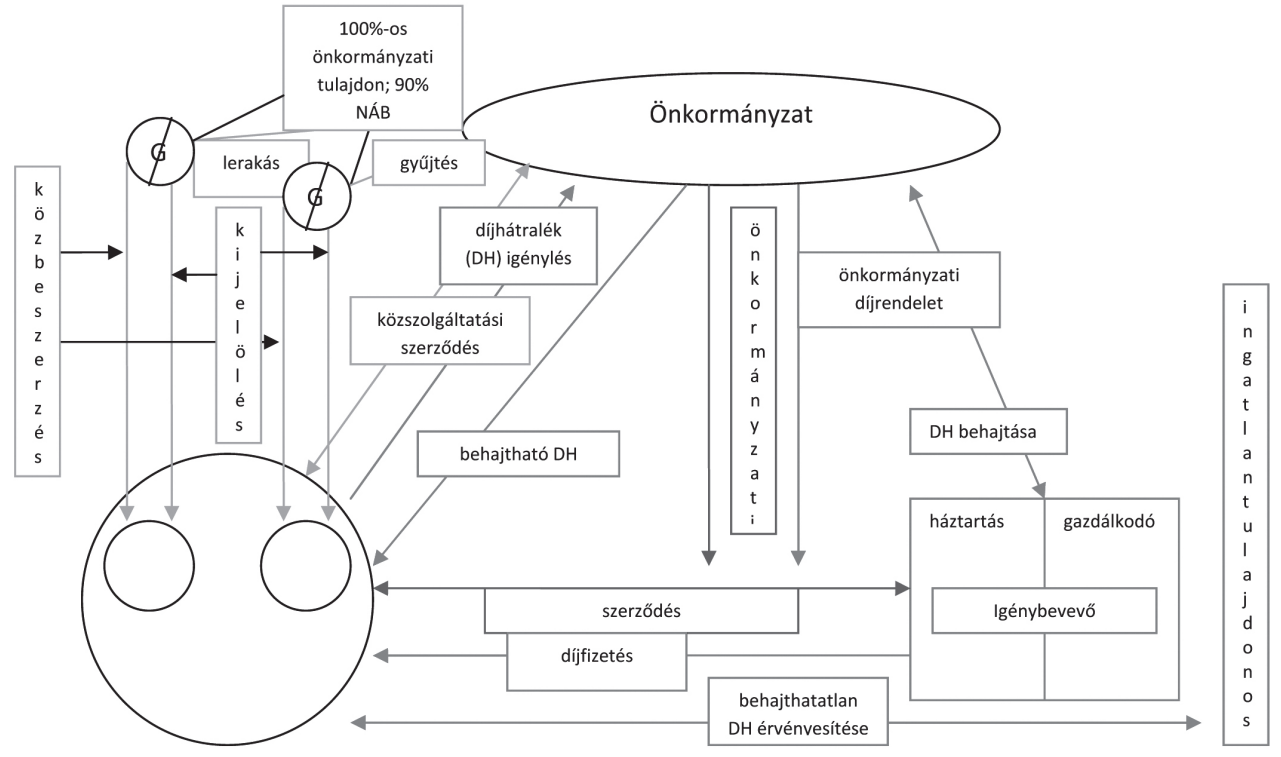

\section{Vegyes modell 2005 után}

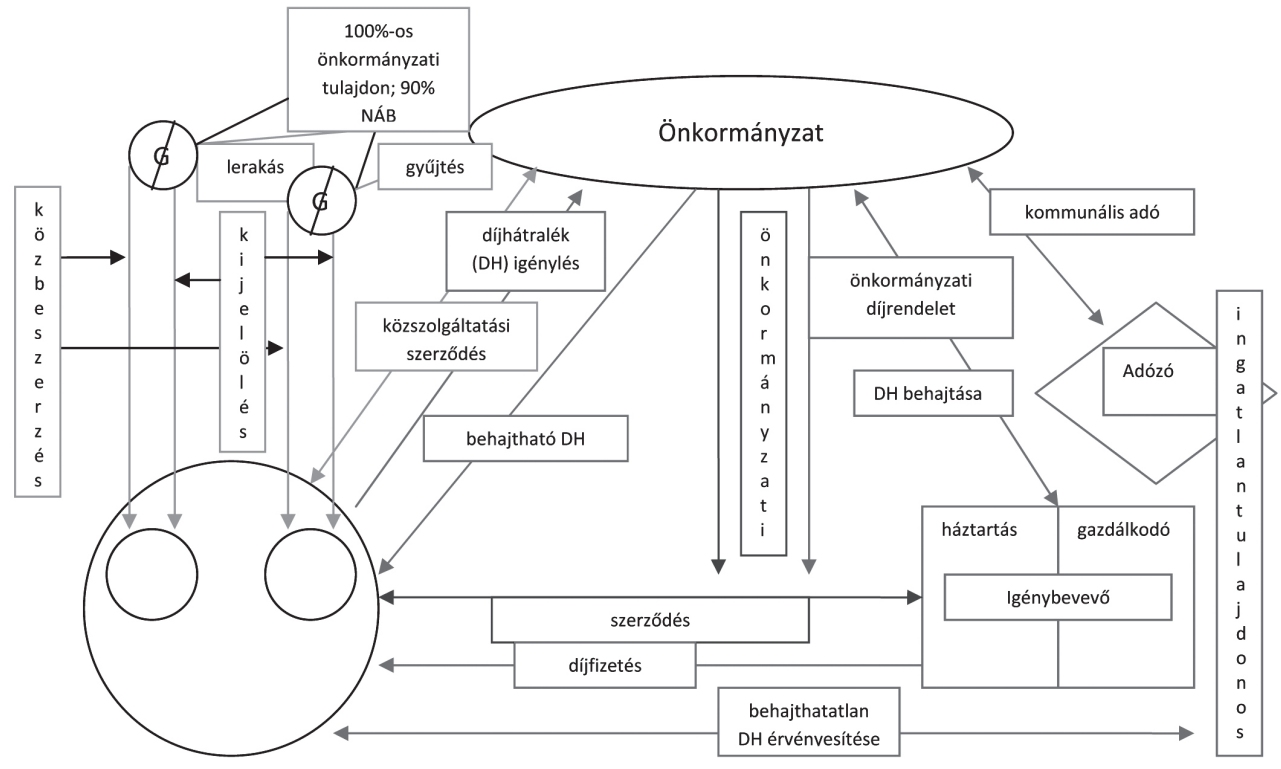




\section{Magyar modell vagy modellek?}

5.1. A fentiek alapján felmerül a kérdés, szükség van-e a három modellre, nem lenne-e jobb, ha a jogalkotó választana közülük, és a modell jellegzetességeihez igazodva alakítaná ki az intézményrendszert.

5.2. A nemzetközi gyakorlatot elemző munkák általában három különböző típusú modellre hivatkoznak: az angolszász, a francia és a német modellre ${ }^{27}$. Az angolszász modellben a piaci eszközök alkalmazását, a szabályozó hatóság (árhatóság) szerepét és funkcióját szokták kiemelni. A francia modellben a magánszektor meghatározó jelenléte miatt a közszolgáltató és az önkormányzat közötti szerződés kap jelentőséget. A német modellben a közszolgáltató önkormányzatról történő leválása miatt az alkalmazható igazgatási kontroll lesz az egyik kulcskérdés. ${ }^{28}$

5.3. Ha a felvázolt magyar modelleket nézzük, akkor azt láthatjuk, hogy az egyes modellekben az angolszász, a francia és a német modell meghatározó jegyei és kérdései egyszerre vannak jelen különböző mértékben és módon, s ezt egészíti ki az önkormányzatok modellek közötti választási szabadsága. Mondhatjuk akkor azt, hogy a magyar modell egy olyan öszvér, ahol a jogalkotó nem tudta eldönteni, hogy melyik külföldi modellt válassza? Véleményünk szerint nem.

5.4. A jelenlegi magyar modellek a rendszerváltás után a hazai hagyományokból nőtték ki magukat. A rendszerváltás előtt is ismert volt a kettős rendszer, a közszolgáltatás ingyenessége és a díffizetés. Ez alapján azt mondhatnánk, hogy már akkor is megvolt a közjogi és a magánjogi modell. Mi úgy gondoljuk, hogy a díj fizetése vagy nem fizetése nem a közjogi és magánjogi modell közötti különbség volt, hanem két közjogi modell közötti, melyben a finanszírozás a közteherviselés elvi alapjában tért el, azaz abban, hogy a fizetőképesség elvét vagy a haszonélvezeti elvet alkalmazták-e ${ }^{29}$.

5.5. A haszonélvezeti elvű finanszírozásra épülő közjogi modellből a rendszerváltást követően magánjogi modell lett. Az Alkotmánybíróság korai döntéseiben ugyanis nem vizsgálta, hogy vajon a díjat lehet-e közjogi oldalról megközelíteni, és egyértelműen a közszolgáltatás szerződéses jellege, a szolgáltatás-ellenszolgáltatás ará-

27 HoRVÁTH munkáiban elsősorban három (angolszász, francia, német) modellt mutat be, rá hivatkozik LÁszLó is. - HorvÁtH (2002): i. m., 58-72; HoRvÁtH (2005): i. m., 39-64; LÁszló-PAP: i. m., 26. HoffmAn 14 európai országban vizsgálja a közszolgáltatás megszervezését az alsó középszintű közigazgatási rendszerekben - Hoffman (2009): i. m., 63-84.

28 Részletesen lásd: HoRvÁTH: (2005) i. m. 39-64.

29 Samuelsonék az adók között különbséget tesznek az alapján, hogy milyen elv érvényesül, a haszonélvezeti elv vagy a fizetőképesség elve. „A haszonélvezeti elv szerint az egyéneket annak arányában kell adóztatni, hogy milyen elönyöket élveznek a különféle, kormányzati programoknak köszönhetően. Ahogy az emberek annak arányában fizetnek a magánjavakért, például a kenyérért, amennyit elfogyasztanak belölük, úgy a fizetendő adó mértékét is a közjavak, például a közutak vagy közparkok használata alapján kell meghatározni. A fizetőképesség elve azt mondja, hogy a fizetendő adóknak az emberek jövedelmével vagy vagyonával kell arányban állniuk. Minél nagyobb egy személy vagyona vagy jövedelme, eszerint annál több adót fizet. A fizetőképességi elvnek megfelelően kialakított adórendszerek általában redisztributív hatásúak, vagyis a magas jövedelmüektől forrásokat gyüjtenek azért, hogy növeljék a szegényebb csoportok jövedelmét és fogyasztását." Paul A. Samuelson, William D. Nordhaus: Economics, Közgazdaságtan (Budapest, KJKKerszöv, 2000, 284). 
nyossága mellett érvelt. Emiatt $a z A B$ a jogalkotónak azt javasolta, hogy a közszolgáltató és az igénybe vevői viszonyt szerződéses viszonyként szabályozza. Az akkor elbírált tanácsi rendeleteket nem tartalmi, hanem formai okok miatt helyezte hatályon kívül.

5.6. Az AB a jogalkotót nehéz helyzet elé állította. Egy olyan viszonyra kellett szerződéses szabályokat kidolgoznia, ahol az egyén szabadságának korlátozása elsődleges, hiszen a közszolgáltatást létrehívó szükséglet elsősorban a közösség, és nem az egyén szükséglete. A közegészségügyi és környezetvédelmi szempontok miatt a közösségi érdek az egyéni érdekkel szemben elsőbbséget élvez. Ezért a (központi és helyi) jogalkotók a felek - mind a közszolgáltató, mind az igénybevevő - szerződéses magatartását részletesen meghatározták úgy, hogy a jogviszonynak nincs olyan létszaka - ideértve a szerződés létrehozását, teljesítést, megszüntetést - melyben akár az igénybe vevő, akár a közszolgáltató szabad megegyezése határozná meg a lényeges jogokat és kötelezettségeket ${ }^{30}$.

5.7. A magánjogi modellben a közszolgáltató és az igénybe vevő közötti jogviszony szerződéses neve ellenére tartalma szempontjából - jogszabályi meghatározottsága miatt - valójában a közjogi modell jogviszonyának felel meg. Ezért a fentiek miatt úgy véljük, hogy mindhárom felvázolt modell közjogi modell, a magánjogi szabályozás csak látszólagos. A modellek közötti különbséget a költségviselési elvek közötti különbség okozza, az, hogy a költségviselés a fizetőképesség elvén, a haszonélvezeti elven vagy a kettő együttesén alapul- $\mathrm{e}^{31}$.

5.8. A fentieket összegezve úgy véljük, hogy létezik egy „magyar modell”, melynek lényegét három dolog együttese határozza meg: a közszolgáltatás közjogi jellege; a költségviselési elvek sokszínüsége, aminek az alapja az önkormányzatok választási szabadsága; valamint a közszolgáltatók gazdasági formáinak és tulajdonosi összetételének változatossága és kötetlensége. Ez nem áll ellentmondásban azzal, hogy az önkormányzatok a három modellben tulajdonosi érdekeltségüktöl függetlenül lényegesen különböző szerepeket töltenek be, finanszírozási felelősségük, pénzügyi kockázatviselésük jelentős mértékben eltér.

5.9. A jelenlegi szabályozás problémáját abban látjuk, hogy a Hgt. a létező különbségek ellenére a három modellt nem különböztette meg egymástól, az önkormányzat eltérő szerepét nem szabályozta átlátható módon, a rendszer müködéséhez szükséges garanciális szabályokat nem építette ki. Az állam az évek során saját szerepét, valamint a modellek szereplőinek viszonyrendszerét a jogszabályi feltételek módosításával lényeges pontokban megváltoztatta anélkül, hogy a változás következményeinek kezelésére megteremtette volna a szükséges eszközöket.

30 A szerződési szabadság elemei: a szerződéskötési szabadság, a partnerválasztás szabadsága, a szerződési típusszabadság és a diszpozitivitás elve közül egyik sem érvényesül. A szerződési szabadság elemeiről lásd LÁBADY Tamás: A magyar magánjog (polgári jog) általános része, Budapest-Pécs, Dialóg Campus Kiadó,1998, 134.

31 Ezt erősítik az Alkotmánybíróságnak azok a döntései is, melyek a felhatalmazáson alapuló, és azzal összhangban álló önkormányzati rendeleteket a szerződési szabadság korlátozására hivatkozva megtámadó beadványokat rendre elutasították. Lásd többek között: 992/H/2001 (2002. XII. 12.), 90/B/2002 (2003. II. 26.), 2003/436/B (2006. IV. 4.), 932/B/2005. AB-hat. (2009. X. 27.). 
Mindezek miatt általános érvénnyel nem állapítható meg, hogy a hulladékkezelési közszolgáltatás területén meglévő problémák kialakulása az önkormányzatok alkalmatlanságára vezethető vissza, vagy önmagában a méretgazdasági szempontok érvényesítése a közszolgáltatás finanszírozását megoldaná.

5.10. A „magyar modellben” az igénybe vevő és a közszolgáltatás megszervezéséért felelös önkormányzat közötti költségviselést az önkormányzat döntötte el, s a kielégítendő szükséglet meghatározásában is jelentős szerepet töltött be. Ha az önkormányzatot felváltja az állam, akkor mindazok a döntések, melyek helyi szinten a helyi viszonyokhoz igazodva születtek, központi szinten dölnek el.

5.11. A jelenlegi rendszerben a közszolgáltatás megszervezése szempontjából az állami szerepvállalás külső feltételnek számít. Ha az állam átveszi az önkormányzatoktól a feladatot, akkor ezzel egy olyan rendszer részévé válik, mely a helyi viszonyok sokszínűségéhez igazodva alakult ki.

5.12. A közszolgáltatás müködési zavarai miatt szükségesnek tartjuk az eddigi szabályozás felülvizsgálatát és a szabályozás újragondolását, de fontosnak tartjuk kiemelni, hogy létezik egy hagyományokra épülő „magyar modell”, melyröl az önkormányzatok nélkül nem beszélhetünk, ugyanis az önkormányzat nem cserélhető fel az állammal. Véleményünk szerint önmagában nem a „magyar modellel”, hanem annak szabályozásával, a szabályozás alapján kialakult joggyakorlattal van baj, azonban ennek bemutatására e tanulmány keretein belül már nincs lehetőségünk.

\section{Abstract}

There is an ongoing debate on how the role of municipalities should be changed in the local public service sector due to the financial problems present at local level. The debate is mainly related to determine the adequate level and function of local governments. The author introduces the basic elements of a model of public services that shows the relationship between the public actors (state/municipality), the service provider and the user, including how the need is determined, the service is provided, financed and the service provider is chosen. The author introduces the "Hungarian Model" and its main features: the co-existence of three different model (public, quasi private and mixed) of the waste treatment service sector differing in the relationships established among the stakeholders and in the financing system; and the right of municipalities to freely switch between them. It draws the attention to how the changes in the role of the state and the legal framework influenced the models and reshaped the relationships of the stakeholders without dealing with the consequences. 